Revue

Revue de l'histoire des religions

del'histoire

des religions

$3 \mid 2017$

Varia

\title{
"Il demone nell'ampolla": Solomon, Virgil, Aeolus, and the Long Metamorphosis of Rain Rituals and Wind-Taming Practices
}

"Le diable dans la bouteille». Salomon, Virgile, Éole et la longue métamorphose des rituels de la pluie et des pratiques d'apprivoisement du vent

\section{Allegra lafrate}

\section{OpenEdition}

\section{Journals}

Electronic version

URL: http://journals.openedition.org/rhr/8752

DOI: ERREUR PDO dans /localdata/www-bin/Core/Core/Db/Db.class.php L.34 : SQLSTATE[HYOOO]

[2006] MySQL server has gone away

ISSN: 2105-2573

\section{Publisher}

Armand Colin

\section{Printed version}

Date of publication: 1 September 2017

Number of pages: $387-425$

ISBN: 978-2-200-93127-8

ISSN: 0035-1423

\section{Electronic reference}

Allegra lafrate, "'Il demone nell'ampolla": Solomon, Virgil, Aeolus, and the Long Metamorphosis of Rain Rituals and Wind-Taming Practices", Revue de I'histoire des religions [Online], 3 | 2017, Online since 01 September 2019, connection on 08 January 2021. URL: http://journals.openedition.org/rhr/8752 ; DOI: https://doi.org/10.4000/rhr.8752 


\section{"Il demone nell'ampolla": Solomon, Virgil, Aeolus, and the Long Metamorphosis of Rain Rituals and Wind-Taming Practices}

The analysis I propose here aims at demonstrating that the cliché of the demon in the bottle, very popular in Western culture, does not represent the mere visualization of a standard wizardry tool or of a simple folklore motif, even if, as such, it enjoyed a broad chronological and geographical diffusion. My contention is that the story of the devil entrapped in a container resulted from the encounter of two different and distinct notions: an archaic concern, springing from the desire to control natural forces, particularly winds, and a more recent habit of associating solid vessels and evil spirits, which developed mostly around the end of the first century C.E. onwards, particularly in Jerusalem. Successively, through the pseudo-epigraphic text known as the Testament of Solomon, both traditions were ascribed to King Solomon who, from Late Antiquity onwards, was strongly associated with the domain of demonology, thus becoming a sort of necromancer par excellence.

« Le diable dans la bouteille ». Salomon, Virgile, Éole et la longue métamorphose des rituels de la pluie et des pratiques d'apprivoisement du vent

L'analyse que je propose ici vise à démontrer que le cliché du démon dans la bouteille, très populaire dans la culture européenne, ne représente pas seulement la visualisation d'un instrument typique du magicien ni un simple motif du folklore malgré sa très large diffusion dans le temps et l'espace. Ma thèse est que cette idée du démon emprisonné dans la bouteille est le résultat de la rencontre de deux traditions différentes et distinctes : une conception archaïque, qui a son origine dans le désir de contrôler les forces naturelles (en particulier les vents), et une tradition plus récente, qui, à partir de la fin du premier siècle après J.-C., associe démons et bouteilles, surtout dans le contexte culturel de Jérusalem. Successivement, grâce à la présence combinée de ces motifs au sein du texte pseudo-épigraphique connu comme Le Testament de Salomon, les deux traditions furent attribuées à Salomon qui, à partir de l'antiquité tardive, était associé à la démonologie et incarnait le rôle du nécromant par excellence. 
Ipse etiam quandoque fui servire coactus germano cuidam, crystalli in corpore clausus sed me barbatus tandem fraterculus illis exemit vinclis, et fracto carcere fugi. (Marcellus Palingenius Stellatus, Zodiacus Vitae, X, 805-8)

The final scene of I Married a Witch, a romantic comedy directed by René Clair in 1942, shows Veronica Lake - the witch of the title - luring the spirit of her father into a whiskey bottle and corking him inside. The wizard Daniel, who up until this point has strongly opposed his daughter's marriage to a mortal man, against whom he has sworn eternal vengeance, can do nothing but resign himself to spending the rest of his days drunk and harmless inside the container. Although the movie was based on The Passionate Witch, a 1941 novel by Thorne Smith, the final twist of the story represents, on a humorous note, the final link in a long-established chain of tropes featuring demons entrapped in various containers, such as flasks, bottles, ampoules, phials, decanters or even lamps.

The motif is so widespread that it also features in the AarneThomson Motif-Index of folktales (nr. 331), the spirit in the bottle, ${ }^{1}$ the most famous example of which is probably the brothers Grimm's version Der Geist im Glas. ${ }^{2}$ It also inspired various literary works even outside the domain of oral or anonymous tradition, such as Robert Louis Stevenson's The Bottle Imp (1891), Alain-René Lesage's Le diable boiteux (1707), which in its turn was partly based on the Spanish work El Diablo cojuelo (1641)

* I would like to thank Sandro Bellesi, Grazia Biondi, Jean Patrice Boudet, Ra'anan Boustan, Richard Camber, José Carrasquer Zamora, Alice Cavinato, Augusto Cosentino, Claudia Daniotti, Margherita Farina, Zev Farber, Rosa Lupoli, Matteo Martelli, Cesare Santus and Vladimir Shelestin and the anonymous reviewer who, in various measures, have all contributed to this article. I am also particularly indebted to the Kunsthistorisches Institut in Florenz - Max Planck Institut, for the generous support that has allowed me to carry out this research.

1. Stith Thomson, Motif-Index of Folk Literature: a classification of narrative elements in folk tales, ballads... Helsinki: Suomalainen Tiedeakatemia,1932-1936. The motif in fact features prominently in folk-tales from around Europe; for a full list, see Hans-Jörg Uther, The Types of International Folktales, Helsinki, Suomalainen Tiedeakatemia, 2004, 3 vols, II, p. 221-2.

2. Jacob und Wilhelm Grimm, Kinder- und Hausmärchen, Wien und Leipzig, Verlag von Martin Gerlach \& Co., 1812-1850, 3 vols, II, nr. 99. 
by Luis Vélez de Guevara. ${ }^{3}$ Folklorists have noted that the motif is first documented in Europe in the Middle Ages, with an Oriental origin (Jewish and Arabian). ${ }^{4}$ As I will show, this latter point is not entirely accurate.

In a way, most of these stories could be inscribed within the larger theme of the covenant with the Devil, since, despite many variations, the imprisoned spirit tends to grant wishes or to favour its possessor, until something else occurs and the protagonist finds himself at the Devil's mercy, following the well-established Faust topos. What I am mostly interested in, here, however, is really the relationship between the demon and its receptacle.

Interestingly, bottles et similia, after enjoying a particularly enduring relationship with evil spirits, seem to have acquired some of their special traits. Such familiarity is in fact reflected, at least in some languages, in the name of various containers that, for different reasons, are endowed with peculiar features. Such is the case, for instance, with the so-called Cartesian diver, or 'Diavoletto di Cartesio'5 (i.e. Cartesian devil), whose original name was actually ludione, a small buoy, often made in the shape of a devil [ill. 1], which alternatively floats and sinks in a bottle used to measure the pressure of liquids, described during an experiment in 1648 by Raffaello Magiotti, who invented it. ${ }^{6}$ The iconography of the devil

3. Robert Louis Stevenson, The Bottle Imp, "New York Herald", FebruaryMarch 1891 (collected in Island Night's Entertainments); Lesage, Le diable boiteux, Paris, Veuve Barbin, 1707; Luis Vélez de Guevara, El Diablo cojuelo, Madrid, Imprenta del Reyno, 1641.

4. Uther, The Types of International Folktales, p. 221.

5. As such, for instance, it is described in Antonio Maria Traversi, Elementi di fisica generale, Venezia, Antonio Curti, 1822, vol. VI, p. 162-3.

6. Raffaello Magiotti, Renitenza certissima dell'acqua alla compressione. Dichiarata con varij scherzi in occasion d'altri problem curiosi, Roma, Francesco Moneta, 1648, fig. VI. For the experiment, Magiotti explained that, instead of the usual "areometri", i.e. in this case "caraffelle" "vials" in practice, small cylinders), one could use "figurine". These are usually glass figurines, with the body full of water and the neck full of air. Originally this kind of device was called "ludione" (lit. "toy"). The reference to Cartesio, its current popular name, got attached to it later on. For the description of the ludione and of its workings, see the catalogue entry n. 29 at the end of the volume Raffaello Magiotti. Uno scienziato di Montevarchi alla corte di Galileo, Accademia Valdarnese del Poggio, Quaderno 9, Città di Castello, Sograte Srl, 1997, p. 187-9 and Luigi Belloni, "Schemi e modelli della macchina vivente nel Seicento, con ristampa della lettera di R. Magiotti Renitenza certissima dell'acqua alla compressione (Il "Diavoletto di Descartes")", Physis 5 (1963), p. 259-98, esp. 282-4. 
in relation to the experiment was apparently first introduced by Athanasius Kircher in $1654 .{ }^{7}$ [ill. 2]

Similarly, most amateur magicians know the trick called the Devil's flask or the Devil's bottle (originally 'Bologna bottle'), performed with a special container, made using a peculiar heating process, almost unbreakable from the outside, but extremely fragile on the inside, which can therefore be spectacularly struck without shattering, or destroyed with a very gentle touch, depending on where it is hit. ${ }^{8}$

It is also well known that, during séances, certain mediums used bottles filled with phosphorus that produced a peculiar glow once uncorked thanks to the chemical reaction caused by contact with air, ${ }^{9}$ or that they were used for magical effects. ${ }^{10}$ Finally, it should not be forgotten that in modern times the profitable evocation or depiction of the devil on a bottle is frequently chosen for commercial reasons, to promote the sale of alcohol. ${ }^{11}$

The analysis I propose here, therefore, begins with a reconstruction of some notable examples of this specific line of interest, through which I aim to demonstrate that the cliché of the demon in the bottle does not represent the mere visualization of a standard wizardry tool; I am in fact convinced that, originally, there was

7. Athanasius Kircher, Magnes, sive de arte magnetica, Roma, Vitalis Mascardi, 1654 , p. 128-9, 131. On the genesis of the name of the device see Gilberto Govi, "In che tempo e da chi siano stati inventati i ludioni detti ordinariamente: Diavoletti cartesiani", Rendiconto dell'Accademia delle Scienze fisiche e matematiche, 18 (1879), p. 291-6. On the figurative history of the Cartesian diver, see the exhibition "Danzad, danzad, diablillos", una visión de la historia del Diablo cartesiano a través de imágenes organized under the supervision of José Carrasquer Zamora at the Universidad de Zaragoza, http://web-ter.unizar.es/cienciate/expo.

8. This typology of container is known as the "Bologna bottle", since it was first described in the Italian city during the seventeenth century; on this, see the first letter by Iacopo Belgradi to Scipione Maffei, Epistolae quatuor de rebus physicis $\&$ antiquis monumentis sub retina recens inventis, Venetiis, Jo. Baptiste Pasquali, 1749 , pp. 1-12, dedicated to "de sphaeris vitreis magno fragore dissilientibus". See the entry "Bologna vial" in Arnold James Cooley, A cyclopaedia of six thousand practical receipts and collateral information in the arts manufacturers ... Boston, D. Appleton \& Co., p. 124.

9. Professional magician John Mulholland describes the process in his book Beware of Familiar Spirits, C. Scribner's sons, New York, 1938, p. 104.

10. A description of these fire bottles is to be found, for instance, in the handbook A Sequel to the Endless Amusement, containing nearly four hundred interesting experiments...to which are added recreations with cards, London, Thomas Boys, Ludgate Hill, 1825, p. 34-5.

11. Several beer, wine and liquor brands have in fact used the image of the devil on their labels. 
at play a deeper and more archaic concern, springing from the desire to control natural forces, particularly winds, entrapped in leather bags, but that, at a certain moment, this idea mingled, in the Western tradition, with the more recent habit of associating solid vessels and evil spirits, which developed mostly from the end of the first century C.E. onwards.

My investigation follows a long arch of centuries, beginning in modern times and proceeding backwards through history. For the first part of my analysis, and in consideration of the abundance of material at my disposal, I have chosen to follow the apparition of demons in bottles mostly in the literature and history of the Italian peninsula, ${ }^{12}$ where they seem to enjoy a particular favour, as is also indirectly attested by the expression "avere il diavolo nell'ampolla" (literally "to have the devil in the ampoule"), not very commonly used anymore, but registered by paremiology and lexicography on the basis of textual occurrences going back at least to the fourteenth century, that is, to the origin of the Italian vernacular language itself. ${ }^{13}$

I will then try to show how this topos penetrated European culture through magical and legendary traditions widespread in the Mediterranean area over the course of the Middle Ages, by suggesting that, although the individual elements had been known since ancient times, they crystallized into the form better known today and enjoyed a broad circulation, first thanks to their association with the figure of Virgil as a necromancer but ultimately through the mediation of King Solomon, who, from Late Antiquity onwards, was strongly associated with the domain of demonology.

\section{“AVERE IL DEMONE NELL'AMPOLLA"}

The Vocabolario della Crusca explains the proverbial expression "avere il diavolo nell'ampolla" as describing someone

12. For a long list of parallels in other European countries, see Johannes Bolte and Georg Polivka, Anmerkungen zu den Kinder- und Hausmärchen der Brüder Grimm, Leipzig, Theodor Weicher, 1915, II, p. 414-22.

13. Vocabolario degli Accademici della Crusca, Venezia, Giovanni Alberti, 1612 , p. 53 , p. 258-9; Niccolò Tommaseo and Bernardo Bellini, Dizionario della lingua italiana, 8 vols, Torino, Utet, 1865-1879, consulted online at www. tommaseobellini.it/\#/. 
who is hard to fool because he is endowed with particular sagacity and perspicacity, capable of foreseeing the consequences of actions. Such a notion depended on the belief that necromancers, who were often credited with the possession of containers full of certain devils, could obtain from them the knowledge of things to come.

We owe to Adolfo Albertazzi (1865-1924), a writer, teacher and scholar belonging to the circle of Carducci in Bologna, one of the latest apparitions of this peculiar type of tool. In 1918, he published a short story appearing in the homonymous collection $\mathrm{Il}$ diavolo nell'ampolla, ${ }^{14}$ translated as The Devil in the Decanter,,${ }^{15} \mathrm{a}$ humorous tale about a mischievous and stubborn demon that ends up entrapped by chance in the water decanter of a lawyer who, from that day on, never loses a case. ${ }^{16}$ After a lifetime of illicit profits, however, the man repents and leaves the decanter with its dangerous contents to a venerable friar, hoping that he may be able to get rid of the evil spirit without any harm. In an ironic twist, however, it is the friar himself who ends up being possessed, after breaking the decanter for not very pious reasons. And while all sorts of exorcisms are attempted in order to free him, to no avail, the demon is eventually forced to a hasty and definitive escape due to the soporiferous effects of a learned lecture, given by a famous German scholar visiting the convent, on the history of comparative demonology from Late Antiquity onwards. Excessive erudition, Albertazzi seems to warn us, is worse than any black magic.

If the writer chose to make use of these elements for his tale, it is because the ampoule with its demon had come to be considered a distinctive tool of wizards and necromancers, turning into a sort of recognizable iconographical feature, as in a painting by

14. Adolfo Albertazzi, Il demone nell'ampolla, Milano, Treves, 1918, pp. 179-194.

15. A full translation of this tale by Traci Andrighetti can be read online at: www.wordswithoutborders.org/article/the-devil-in-the-decanter.

16. "Una sulfurea fiammella che roteava a mezz' aria e si dirgeva, pari a una freccia, verso di lui. In un istante, per istintiva difesa, egli afferrò di su la scrivania ciò che gli venne alle mani, e fu l'ampolla dell'acqua con cui allungava le chiacchiere da inzeppare i clienti; e il caso volle che seguendo a un punto il solevamento della boccia inclinata e l'obliquo arrivo del globulo di fuoco, questo s'infilasse dentro di quella. Sfrigolò, sobbalzò: invano; vi rimase, perché l'avvocato, più svelto del diavolo, appose all'ampolla il tappo e lo rigirò e suggellò ben stretto", Albertazzi, Il diavolo nell'ampolla, p. 180. 
Pier Dandini ${ }^{17}$ [ill. 3]. It is not to be excluded that at some level the popularity of this idea, at least visually, was reinforced by the strong formal similarity with the alembic in which alchemists staged various transformation processes [ill. 4] and in which they aimed at creating the homunculus, which was represented as a small creature closed in a vessel, a theme made particularly famous through the writings attributed to Paracelsus, and eventually through Goethe's Faust [ill. 5], but in subterranean circulation a few centuries earlier. ${ }^{18}$ However, despite the possibility of a visual and cultural intersection between these themes, the story of the demons in the ampoule, as I will try to show, probably grew and developed independently from potential alchemical parallels.

The issue of demons locked up in decanters had not always been good joke material; on the contrary it could be the cause of some serious allegations, as the famous case of poet Alessandro Tassoni (1565-1635) demonstrates. The celebrated author of La Secchia Rapita (The Stolen Bucket), a mock-heroic poem published in 1622, was accused of having an ampoule complete with demon. The event is well documented and it has been recently reconstructed in detail

17. The painting is indexed as Evocazione di demoni by Sandro Bellesi, Diavolerie, magie e incantesimi nella pittura barocca fiorentina, Firenze, Giovanni Pratesi Antiquario, p. 65-9; more recently, the scene has been identified by Philippe Morel as Ismen, being probably based on the description of Torquato Tasso's Gerusalemme Liberata (XIII, 43); see Philippe Morel, "La figure de la magicienne de l'Orlando Furioso à l'art florentin entre Cinquecento et Seicento", in L'arme e gli amori: Ariosto, Tasso and Guarini in late Renaissance Florence, ed. Massimiliano Rossi and Fiorella Gioffredi Superbi, Firenze, Olschki, 2004, vol. II, p. 297-325, p. 323-5. A famous earlier example of witches handling an ampoule with a demon inside is to be found in Hans Baldung Grien's The Weather Witches. On this, see Linda Hults, "Hans Baldung Grien's Weather Witches in Frankfurt", Pantheon 40 (1982), p. 124-30; Linda Hults, "Baldung and the Witches of Freiburg: the Evidence of Images", Journal of Interdisciplinary History 18 (1987), 249-76; Charles Zika, The Appearance of Witchcraft, London, Routledge, 2007, ill. 3.12; the scholar posits that besides its usual connection with witches/wizards, the ampoule in this case could hint at "the illicit involvement of aquavit women in the manufacture of distilled waters for malefic purposes", p. 84-5; see p. 247 n. 43 and ill. 3.22.

18. The idea of creating life from matter was already attributed to Simon Magus who, in the Recognitions attributed to Clement (ch. XV) was said to have made a boy out of air. However, such a theme is only distantly related to ours. In that experiment there is no reference to any vessel. For the description in Paracelsus, De natura rerum, see Sämtliche Werke. Medizinische, naturwissenschaftliche und philosophische Schriften, ed. Karl Sudhoff, Munich, R. Oldenbourg, 1927, 14 vols, XI, p. 316-7. It is interesting to note that even Paracelsus was credited with the possession of a bottled demon; see Bolte and Polivka, Anmerkungen, p. 415. 
through archival sources. ${ }^{19} \mathrm{We}$ also have account of the episode in Tassoni's own hand, in a three-page-long letter, dated February $9^{\text {th }} 1602$, addressed to the Vicar of the Inquisition of Modena but possibly never sent, in which he describes all the facts, declares his innocence and explains how the absurd accusation had taken shape. Entrusted with the legacy of Girolamo Poliziano, he had found among the possessions of the defunct a glass ball with a glass demon inside. He explained that such objects were produced in Murano and could contain all sorts of figures, such as oxen, donkeys or a Zanni, one of the typical characters of Venetian popular theatre, and were exported around the country. The ball had probably been acquired through a certain Bastaglia, who was known for such commerce. It had been the object of some laughter among the poet and the maidservants, who joked about the fact that the deceased kept a demon in an ampoule, and so the rumour that he had subsequently taken possession of it had begun to spread, since the item was never included in the inventories. Tassoni, in fact, declared that he had given it to a child for his amusement and to have lost trace of it. ${ }^{20}$

If the episode of Tassoni, oscillating between ignorance, misunderstanding and defamation, might appear slightly amusing to our eyes, its possible consequences could have been very serious indeed. In the Sacro Arsenale, ouero Prattica dell'officio della Santa Inquisizione, the earliest practical handbook for inquisitorial officers in the vernacular, the first definition of "maghi, streghe, incantatori e simili" (wizards, witches, bewitchers, etc.) concerned precisely those who imprisoned demons in rings, mirrors, medals,

19. The episode has been extensively reconstructed by Grazia Biondi, "Quel 'diavolo' di Tassoni” (provisional title), paper presented at the conference Alessandro Tassoni. Poeta, erudito, diplomatico nell'Europa dell'età moderna, Modena, November 6-7, 2015; the proceedings of the conference are in the process of being published but through the author's kindness I was able to access her contribution beforehand.

20. Tassoni describes the glass ball as "una boccetta di vetro della grossezza d'un uovo d'oca... non avea adito, né spiraglio alcuno, e nondimeno era piena d'acqua senza che ve ne mancasse una goccia...ma quel ch'è peggio avea un Demonio dentro: dico un Demonio, che non era cosa imaginaria, ma si vedeva cogli occhi far capitomboli quando si voltava la boccia, e fermarsi ritto che pareva un signore. Egli è vero...ch'egli era di vetro anch' egli come la boccia: ma che importa; basta che egli era un Diavolo, et avea le corna, ed il viso negro che parea un inchiostro", Le lettere di Alessandro Tassoni, tratte da autografi e da copie e pubblicate per la prima volta nella loro interezza da Giorgio Rossi, Bologna, Romagnoli-Dall'Acqua, 1910, vol. II, p. 125-136, esp. 127-8. 
ampoules and other things, ${ }^{21}$ a very similar description occurs in the exorcism handbook written by the Observant friar Girolamo Menghi in $1586,{ }^{22}$ whose very phrasing seems to have been drawn directly from the condemnation of people worshiping demons in ampoules that appeared in the papal bull Coeli et terrae creator Deus, issued by Sixtus V a year earlier and almost immediately translated into Italian as well. ${ }^{23}$

Unsurprisingly, given this scenario, in the century and a half preceding Tassoni's incident, and in parallel to these publications, several trials were held, in the area of Modena, against people who were accused of having a "sfera vitria" or a "balla vitria" replete with demon. ${ }^{24}$ Suspicion toward ampoules and their dangerous content was extremely widespread, as much as the habit of owning one, probably. Various sources underline how this was popular both among common people - particularly liked, for instance, by credulous women who were prone to take an innocuous toy for a disquieting magical tool - but also among more learned figures. ${ }^{25}$

21. "Quelli che tengono costretti (com'essi pretendono) demoni in anelli, specchi, medaglie, ampolle o in altre cose", Eliseo Masini, Sacro Arsenale ouero Prattica dell'officio della Santa Inquisizione, Genova-Perugia: Sebastiano Zecchini, 1653, p. 18.

22. Girolamo Menghi, Compendio dell'arte essorcistica et possibilita delle mirabili et stupende operationi delli demoni et dei malefici, Bologna, Giovanni Rossi, 1586, p. 77-8.

23. Constitutio S.D.N.D. Sixti Papae Quinti contra exercentes astologiae iudiciariae artem: "[...] aut annulum, vel speculum, aut parvas phyalas sibi fabricant, aut fabricari curant ad daemones in eis alligandos, seu includendos, ut putant, ad responsas ab ipsis inde petenda, aut habenda", Magnum Bullarium Romanum, Lugduni, Laur.Arnaud \& Petri Borde, 1692, II, p. 515-7. In 1586, the text of the bull was also translated into Italian by cardinal Gabriele Paleotti, Contra coloro ch'essercitano l'arte dell'astrologia giudiciaria, \& qualunque altra sorte di divinationi, sortilegij, superstitioni, strigarie, incanti \&c., Roma, Stampatori camerali, 1586 (reprinted in Bologna by Alessandro Benaci in the same year), p. 9: "Si fanno, o si fan fare, anelli, overo specchi, ò picciole ampolle per legare, come pensano, ò rinchiudere in quelle i Demonij per dimandarli poi delle risposte, ò riceverle". For a detailed study on the text, see Germana Ernst, Religione, ragione e natura. Ricerche su Tommaso Campanella e il tardo Rinascimento, Franco Angeli, Milano 1991, p. 255-79.

24. For a detailed list of cases, see Albano Biondi, "Streghe ed eretici nei domini estensi all'epoca di Ariosto", in Il Rinascimento nelle corti padane. Società e cultura, ed. Paolo Rossi et al. Bari, Laterza, 1975, p. 165-99, esp. p. 175-6.

25. We know from Ludovico Ariosto, Satire, VII, 94-95 that Carlo Sosena, who taught astrology at the Studium in Ferrara and was an astrologer at Duke Ercole's court, made prophecies thanks to a spirit. 
The question was matter of some debate: Francesco Diacceto (1531-1595), for instance, in his Sopra la superstizione dell'arte magica (1568), dedicates a lengthy passage to a detailed demonstration, which showed how, in rational, philosophical and theological terms, it was not possible for an incorporeal spirit to be imprisoned within physical boundaries unless a superior agency was involved. The ampoule, as a repository, was therefore considered almost fortuitous and not especially binding according to this view. ${ }^{26}$

The custom was accepted and well in use in the courts. In a letter addressed in 1495 to the Duke Ercole of Este, the court astronomer of Ferrara, Giovan Maria de Albricis, describes to his prince a series of events to come, related to the passage of a specific constellation that, allegedly, had been revealed to him by certain spirits that he kept enclosed in small ampoules. ${ }^{27}$

The topos of the necromancer with this type of object already seems to be crystallized in the fourteenth century, as a poem by Franco Sacchetti, dedicated to all sort of magic practices, shows well. ${ }^{28}$ In fact, traces of this idea are clearly also found in the anonymous contemporaneous description of the battle of Montaperti (1260), probably in a fourteenth-century interpolation. According to the compiler of the account, the condottiero of the Florentine troops had been foretold his death in the forthcoming military action by a demon kept in the familiar container. ${ }^{29}$

26. "[...] i magi non possono constrignere spiriti, ne rilegarli in anella, in ampolle, in imagini, in vetri o in altri luoghi: se non in quanto, che gli hanno lega, o patto con alcuno spirito superiore. Conciosia che quelli che tra essi sono superiori, habbiano valore et forza di strignere gli inferiori: per esse tra loro certo ordine di superiorità". For the full passage, see Francesco de Cattani da Diacceto, Discorso sopra la superstizione dell'arte magica, Firenze, Valente Panizzi \& Marco Peri C., 1567, p. 15-18v.

27. "Et questo per certi spiriti quali io aveva incluso in una ampolina", quoted by Fernando Gabotto, Nuove ricerche e documenti sull'astrologia alla corte degli Estensi e degli Sforza, Torino: La Letteratura, 1891, p. 7

28. The poem, n. 90 (or 46 according to other numbering systems) in the collection of the Rime, is a veritable catalogue of false prophets, astrologers, sibyls, heretics, foretellers, dream interpreters, etc., as they are known and attested in 1378. The poet concludes his description by mentioning necromancers with the inevitable ampoule: "ne' nigromanti finirà il mio motto / che ognuno è Michel Scotto,/ dicendo ne l'ampolla il diavol hanno, / e con fatture assai corpi disfanno", Franco Sacchetti, Opere, ed. Carlo Borlenghi, Milano, Rizzoli, 1957, p. 1071-75, vv. 100-104.

29. "[...] el chapitano de' Fiorentini si era negromante e aveva el diavolo rinchiuso in una lampolla, e sì 'l costrense e dimandò se doveva morire di quella bataglia. E'l dimonio li rispose che lui no morebe se non fusse tra 'l bene e 'l male. 
The story of the demon and of its vessel, in general, always seems to oscillate between two opposing poles: the danger of damnation and the harmlessness of a joke. And it is probably not a coincidence that the theme is either mentioned in comedy texts, by authors who favor it as a target for laughter, irony or ridicule, ${ }^{30}$ or in trial papers and spiritual handbooks, as we have seen, by those who are in charge of the salvation of souls. What appears to be condemned, in this latter case, in fact, is always the attitude and belief in the object, not the effectiveness of the thing in itself, which is usually doubted, when not explicitly denied.

It is to be noted, moreover, that in several cases the ampoule appears to be included in lists also containing mirrors, which seems to imply that it was possibly equated or confused with a specific genre of divination known as scrying, based on the reading of polished surfaces, such as blades, glass, fingernails, stones and also water reflected in translucent containers. ${ }^{31}$ An erudite note by Paolo Minucci to Lorenzo Lippi's Malmantile seems to confirm that, at least in certain cases, this was the idea behind the ampoule. ${ }^{32}$

According to these methods, one could predict the future thanks to the indistinct and vague images perceived on the object. It is not difficult to see how the idea of an ampoule containing a liquid could also be included in this category. However, despite this common association found in the later sources mentioned above, the ampoule containing a demon seems to differ slightly in various respects from the typology of divination just described.

E in questo modo parlò el dimonio", Cronache Senesi, eds. Alessandro Lisini and Fabio Giacometti, in RR.II.SS., Bologna, Nicola Zanichelli, 1931, XV/6, p. 58.

30. The expression occurs, for instance, in Ariosto's Satires, VII, 94-95, in Agnolo Firenzuola's comedies, I lucidi, Firenze, Giunti, 1552, II, IV, p. 17, in Francesco d'Ambra's comedies, I Bernardi, Firenze, Giunti, 1564, IV, V, p. 71, in a mock-heroic poem by Alessandro Tassoni, La secchia, poema eroicomico d'Androvinci Melisone, Paris, Tussan du Bray, 1622, V, 5.

31. It is the discipline traditionally ascribed to specularii, of which an extensive description is provided by John of Salisbury: "Specularios vocant qui in corporibus levigatis et tersis ut sunt lucidi enses, pelves, ciathi, speculorumque diversa genera, divinantes, curiosis consultationibus satisfaciunt, quam et Ioseph exercuisse aut potius simulasse describitur, cum fratres argueret surripuisse ciphum in quo consueverat augurari", Ioannis Saresberiensis Policraticus, ed. K.S.B. KeatsRohan, Turnhoult, Brepols, 1993, ch. XII, p. 56-72.

32. Perlone Zipoli (Lorenzo Lippi), Il Malmantile racquistato colle note di Puccio Lamoni (Paolo Minucci), Firenze, Michele Nestenus, 1731 (or. ed. 1688), p. 294. 
Even if the demon does provide its master with answers about the future, thus working as a divination method, it does so by actively responding, not as a passive image requiring interpretation. The speaking demon is forced to answer its owner because it is subject to him and performs a function not too dissimilar to that of the genie in the lamp (which formally belongs to the same category of entrapped demons), by granting a wish; in most cases, a wish for knowledge.

I think that it is important to consider this dialectic process of wishing/granting between the master and his enslaved demon, and also to emphasize the speaking dimension of such a relationship, since these are features that, as I wish to demonstrate, lie at the core of the original crystallisation of this topos, at least in what I assume to be its most famous and successful form. Further research in Italian texts could possibly yield other examples but I think that the selection proposed here is sufficient to show the line of uninterrupted continuity, from recent times back to the Middle Ages.

\section{Virgil Magus and the Cumae Sibyl}

Despite the situation outlined in the previous section, it is remarkable that, while the practice of keeping a demon in a phial is certainly well attested, Medieval handbooks of practical magic do not seem to register it more precisely. ${ }^{33}$ Nor is it included in the classification of various typologies of "magi" compiled by Isidore of Seville, which summarises most practices known from classical antiquity (Etymologiae, VIII, 9-35). This fact is rather bizarre. Magic, by definition, is a very conservative genre, guaranteeing a faithful transmission over time. However, despite innumerable examples of texts explaining the details of various demon-binding techniques, on the one hand, and the evidence listed above regarding ampoules, there is nothing that explicitly clarifies how a necromancer was technically supposed to entrap a demon in a flask, not even in a treatise on how to create and conjure a spiritus

33. Even the examples provided by Martin Del Rio in his renowned Disquisitionum Magicarum libri sex, Moguntiae (Mainz), Petri Henningii, 1617, see IV, ch. 2 , quaestio 6 , section 4 , usually a very learned source, quoting several classical occurrences, are all fairly late in date. 
familiaris, which would seem to represent its closest parallel. ${ }^{34}$ Therefore, while the topos is safely established and represents, as we have seen, one of the most distinctive features of the wizard, starting in the late Middle Ages and throughout the Renaissance, we seem to lack a source explaining the details of its origin. The absence of such a protocol is revealing in its own way and seems to suggest that the notion of the demon in the bottle has always been transmitted as a sheer trope without ritual, as the fruit of a narrative, rather than of a magical tradition. For this reason, I believe that it is important to find a strong textual example at the origin of this chain, whose impact might have helped the diffusion and the penetration of the idea in Western culture.

The examples I have been able put together halt at the fourteenth century, at least in Italian sources. However, meaningful traces of the same tradition, predating those listed so far, can be found in earlier literary traditions and constitute, in my view, a fundamental juncture of the transmission process. Some Medieval romances, already in the thirteenth century, attest that the poet Virgil, whose reputation as a magician in post-classical times is well known and studied ${ }^{35}$ possessed or entrapped one or more demons in ampoules

34. On this, see Sophie Page, "Magic and the Pursuit of Wisdom: the 'familiar' spirit in the Liber Theysolius", La corónica. A Journal of Medieval Hispanic Languages, Literatures and Cultures, 36 (2007), p. 41-70. The demon in the ampoule could technically belong to the category of spiritus familiaris but not all "familiar spirits" dwell in vials, which is why, despite various similarities, I have chosen not to use spiritus familiaris throughout this contribution for fear of being misleading. The definition is a broad one and originally indicates a "famulus", that is, a slave spirit, but it can also acquire the meaning of familiar in the sense of intimate. Even Socrates' daimon could be considered a spiritus familiaris, in a way. This class of spirits is not necessarily evil, but it can exert a function of protection, often assimilated with the function performed by guardian angels in the Christian tradition. This notion probably became widespread thanks to the Liber Razielis, a Medieval grimoire, originally in Hebrew, compiled around the thirteenth century. On this, see Sophie Page, "Speaking with Spirits in Medieval Magic Texts" in Conversations with Angels. Essays towards a History of Spiritual Communication, 1100-1700, ed. Joad Raymond, London, Palgrave McMillan, 2011, p. 125-149. For an interesting exposition of the theme during the Modern Age, see Philipp Ludwig Elich, Daemonomagia, Frankfurt, Conradi Nebenii, 1607, p. 194-210, esp. p. 201.

35. Domenico Comparetti, Virgilio nel Medioevo, 2 vols, Firenze, B. Seeber, 1896, II, p. 99-105. The earliest examples are the Reinfried von Braunschweig and the Wartburgkrieg (thirteenth century). Both texts recount how Virgil met a famous necromancer, Zabulon, and took away his books thanks to a spirit enclosed in a ring. Even more pertinent to our case is the Weltbuch written by 
or bottles. ${ }^{36}$ Given the popularity of this figure throughout the Middle Ages, he probably acted as a prototype for the necromancer with the enslaved demon, an idea that successively spread far and wide, thanks to its recurring presence in the literature of various countries.

This fundamental passage, however, only provides a partial answer to our question. How and why did Virgil end up possessing such a peculiar tool? Greek and Roman literature do not seem to abound with demons in ampoules. However, there is a notable exception in the scenario, and a particularly meaningful one, given the setting of the story. The episode I am referring to is that of the Sibyl, mentioned by Petronius in his Satyricon (48.8). ${ }^{37}$ Trimalchio, at the end of dinner, reports that he saw the Sibyl in Cuma imprisoned in an ampoule hanging from the ceiling, surrounded by children scornfully asking her what she wished, to which she replied that she only wanted to die. The episode has remained famous in Western literature, inspiring several writers, philosophers and poets up until the twentieth century. ${ }^{38}$

Considering the strong historical and literary relationship between Virgil, who had given voice to that very Sibyl in the

Jans der Enikel, where Virgil is said to have found a bottle with twelve demons inside while hoeing the ground; Heinrich von Mügeln versified a similar episode; Felix Hemmerlin in his De nobilitate et rusticitate dialogus narrates how Virgil controlled a demon enclosed in a bottle thanks to a book attributed to Solomon.

36. See also Bolte and Polivka, Anmerkungen, II, p. 415-6.

37. "Nam Sibyllam quidem Cumis ego ipse oculis meis vidi in ampulla pendere,


On the text, see Gareth Schmeling, A Commentary on the Satyrica of Petronius, Oxford, Oxford University Press, 2011, p. 206-7. On the interpretation of the episode see H.D. Cameron, "The Sibyl in the Satyricon", The Classical Journal 65 (1970), p. 337-9.

38. As far as Italian literature is concerned, both Vittorio Sereni and Andrea Zanzotto make explicit references to it in their poetic works; see Paolo Orvieto, Un'idea del Novecento: dieci poeti e dieci narratori, p. 191. The most famous quotation, however, is that by T.S. Eliot in the exergo to his poem The Waste Land. A long analysis was dedicated to it by Helen Bacon, "The Sibyl in the Bottle", Virginia Quarterly Review 34 (1958), p. 262-77, by William Arrowsmith, "Luxury and Death in the Satyricon", Arion 5 (1966), p. 304-31 and by Gareth Smeling and David Rebmann, "T.S. Eliot and Petronius", Comparative Literature Studies 12 (1975), p. 393-410. These examples could easily be multiplied; see for instance the bibliographical references listed in Jean-Michel Roessli, "Vies et métamorphoses de la Sibylle: Notes critiques", Revue de l'histoire des religions 224 (2007), p. 253-71, esp. p. 264-5. 
Aeneid ${ }^{39}$ and the fact that most Medieval legends surrounding the poet developed in the geographical area between Naples and Cumae, gaining strength through local reminiscences, it would seem likely that the story of Virgil's demon, transmitted by Medieval romances, could possibly represent the last metamorphosis of the entrapped Sibyl, whose story had been in circulation ever since the end of the first century, and which was also repeated in the course of Late Antiquity. However, despite this cultural and geographical proximity, which I wish to underline here, it is difficult to prove this hypothesis with certainty since, as we will see below, the demon seems to have entered Virgil's legend mainly through a different channel. At least, this is what most texts seem to imply.

The peculiar abode of the Sibyl and its possible parallel and precedents are studied in an article written by Campbell Bonner in 1937, some aspects of which I will now briefly summarise. ${ }^{40}$ After inscribing the episode within the broader imp/bottle motif, Bonner proceeds to find other sources of comparison. He therefore lists a few authors whose writings echo or somehow parallel the Satyricon episode and could somehow explain its etiology. ${ }^{41}$ He mentions Pausanias (X, 12, 8), Pseudo-Justin, Cohortatio ad Graecos (ch. 37) and Lucius Ampelius' Liber Memorialis (VIII, 16), who, in different ways, roughly between the second and the fourth centuries C.E., attest to the idea that in Cumae was preserved a vessel containing the mortal remains of the woman. These sources are not perfectly identical when it comes to the container, either speaking of a cinerary urn, of a bronze bottle or of a cage, and the scholar suggests that "the narratives

39. Emily Gowers, "Virgil's Sibyl and the 'Many Mouths' Cliché(Aen. 6.625-7)", The Classical Quarterly, 55 (2005), p. 170-82.

40. Campbell Bonner, "The Sibyl and Bottle Imps", in Quantulacumque. Studies presented to K. Lake, ed. R.P. Casey and A.K. Lake, London, Christophers, 1937, p. 1-8; see also Paul Veyne, "La Sibylle dans la bouteille", in Hommages à J. Bayet, published in Latomus 70 (1964), p. 718-21.

41. The passage from Apuleius mentioned by Roger Pack and added to the list of possible parallels does not seem convincing from a textual point of view. Here, in fact, the poet mentions a sibyl in a lamp, referring to the fact that lamps could be used for divination purposes, and a lamp could thus, in a figurative way, be considered a sibyl; Roger Pack, "The Sibyl in a Lamp", Transactions and Proceedings of the American Philological Association 87 (1956), p. 190-1. 
that represent the Sibyl as confined, while still alive, in a bottle or a cage, are merely the product of a wonder-loving imagination working upon a more sober story, to the effect that the relics of the venerable prophetess were deposited in a small urn [...] It would be no great stretch of pious fancy to suggest that the voice of the seeress still spoke from her ashes, and the next step, that she was still living, a tiny atom, in an urn or a bottle, might follow readily enough". ${ }^{2}$

While advancing this extremely reasonable hypothesis, however, the author tentatively suggests that the Sibyl in the bottle could represent yet another manifestation of the captive demon folklore motif. Bonner in fact realizes that the origin of the theme is much more ancient and quite widespread outside the Greco-Roman world as well, noting that it could perhaps be related to the idea of the confinement of the winds in a sack, a motif found as early as the Odyssey (X, 1-79), or to that of Pandora's pithos described by Hesiod (Op. 90-95), in which Zeus had shut up plagues and diseases, whose evil characteristics are well identified in the ancient world, but also referring to the numerous examples of entrapped jinn easily found in Arabic texts. The scholar is therefore inclined to consider the Sibyl story as the embodiment of a much more widespread folk-motif, whose actual origin, however, was difficult to clarify, having both "classical" and "oriental" parallels.

Nonetheless, he concludes his contribution by saying that, even if stories involving demons or evil spirits (in the form of winds and plagues) entrapped in jars could certainly be traced back to Homer and Hesiod, and were not therefore entirely unknown to the classical tradition, demons enclosed in bottles were more common to the Judaeo-Christian tradition, where the motif was strongly associated with Solomon, who, in the course of Late Antiquity, was credited with this kind of power, ${ }^{43}$ and to Arabic literature, particularly to some tales from the Arabian Nights.

42. Bonner, "The Sibyl and Bottle Imps", p. 2-3. Of a similar opinion is also L. Richardson Jr., "Trimalchio and the Sibyl ad Cumae", The Classical World 96 (2002), p. 77-8.

43. The scholar also mentions the tradition of magic bowls or incantation bowls, clay vessels with apotropaic functions, often inscribed with Solomonic formulae. However, the corpus of extant pieces, none dating from earlier than the sixth century C.E., probably has nothing to do directly with the tradition of the metal bottles that had developed in connection with Solomon ever since the 
Interestingly, a somehow similar conclusion is advanced by Domenico Comparetti, who underlines how, in the numerous thirteenth-century accounts describing Virgil and the demons, one can find direct traces of Solomonic magic. In all these narrations, in fact, the Solomonic channel of transmission was usually made explicit, an element which brings the author to conclude that to the Latin poet were attributed the features of a well known legend "di provenienza rabbinica e maomettana [...] un racconto che figura nelle Mille e una notte". ${ }^{44}$

Neither of the two scholars insists further on this point or tries to better clarify the origin of the motif in these sources. Comparetti was not interested in that specific aspect: undoubtedly, magic traditions related via Arabic sources constitute one of the main bulks of the magic repertoire of the Western world and it is not surprising to find lines of tangency there. In turn, Bonner suggests that scholars with a better knowledge of Hebrew should pursue that line of research; however, he tentatively posits the existence of a common ancient narrative nucleus ("such a story may once have been current"), which could keep together the Eastern sources dealing with Solomon while explaining the tragic destiny of the Cumae prophetess. ${ }^{45}$

I am convinced that Bonner's thesis deserves close attention and further clarification and that some of his intuitions need to be inscribed within a more complete scenario. In the next section, I will therefore analyze the Solomonic tradition rightfully evoked by both these scholars, trying to show how and why winds, demons, bottles and ampoules came together, thus becoming, in the first stage, one of the most recognizable features of Solomon as an exorcist and, as a consequence, a successful tool of any wellrespected necromancer.

first century. On the typology of these objects, see James Montgomery, Aramaic Incantation Texts from Nippur, Philadelphia: University Museum, 1913; Cyrus Gordon, "Aramaic Magical Bowls in the Istanbul and Baghdad Museums", Archiv Orientální 6 (1934), p. 319-34; Charles Isbell, Corpus of the Aramaic Incantation Bowls, Missoula, The Society of Biblical Literature, 1975; Markham J. Geller, "Eight Incantation Bowls", Orientalia Lovaniensia Periodica 16 (1986), p. 108-10; Shaul Shaked, James Nathan Ford, Siam Bhayro, Aramaic Bowl Spells: Jewish Babylonian Aramaic Bowls, Leiden, Brill, 2013.

44. Comparetti, Virgilio nel Medioevo, p. 103-4.

45. Bonner, "The Sibyl and Bottle Imps", p. 8. 


\section{Entrapping Demons in the TeSTAMENT of Solomon}

Solomon's demon-repelling powers are attested as early as the first century, but the king is explicitly known for entrapping them in closed vessels or containers from the second/third centuries onwards. Our main source for this is the Testament of Solomon, the famous handbook of demonology probably compiled in Constantinian Jerusalem by putting together sources of various kinds and of varying chronology. ${ }^{46}$ The text, widely discussed in terms of its textual, linguistic and cultural origin, can be defined as a veritable catalogue of spirits, which are introduced, described in their evil deeds and finally subjugated by Solomon, by virtue of the authority given by his signet-ring. ${ }^{47}$

The possibility of subjugating demons with such an object can be inscribed within a broader context of learned magic, functioning thanks to the recognized power of words. The exorcist/wizard establishes a relationship with the evil spirit that is no different, in a way, from that created between two contracting parties or, perhaps

46. The Testament of Solomon, ed. Chester Mc Cown, Leipzig, J.C. Hinrichs, 1922; James Harding and Loveday Alexander, "Dating the Testament of Solomon," posted May 28, 1999: http://www.st-andrews.ac.uk/divinity/rt/otp/guestlectures/ harding/; Pablo A. Torijano, Solomon the Esoteric King. From King to Magus, Development of a Tradition, Leiden-Boston, Brill, 2002, esp. p. 76-87; Todd E. Klutz, "The Archer and the Cross: Chronographic Astrology and Literary Design in the Testament of Solomon", in Magic in the Biblical world: from the Rod of Aaron to the Ring of Solomon, ed. Todd E. Klutz, London: T\&T Clark, 2003, p. 219-44; Das Testament Salomos: die älteste christliche Dämonologie, kommentiert und in deutscher Erstübersetzung, ed. Peter Busch, Berlin-New Yok: Walter de Gruyter, 2006; Sarah Schwarz, "Building a Book of Spells: the So-Called Testament of Solomon Reconsidered", PhD thesis, University of Pennsylvania, 2005; Sarah Schwarz, "Reconsidering the Testament of Solomon", Journal for the Study of the Pseudoepigrapha 16 (2007), p. 203-37; Sarah Schwarz, "Review of Todd E. Klutz, Rewriting the Testament of Solomon: Tradition, Conflict and Identity in a Late Antique Pseudoepigraphon", Journal for the Study of Pseudoepigrapha 17 (2007), p. 57-78; Pablo A. Torijano, "Solomon and magic," in The Figure of Solomon in Jewish, Christian and Islamic Tradition, King, Sage and Architect, ed. Joseph Verheyden, Leiden-Boston, Brill, 2012, p. 107-25; Peter Busch, "Solomon as a True Exorcist: the Testament of Solomon in its Cultural Setting," in The Figure of Solomon, p. 183-95; Il Testamento di Salomone, ed. Augusto Cosentino, Roma, Città Nuova, 2013.

47. For the most recent assessment on the topic, see Ra'anan Boustan and Michael Beshay, "Sealing the Demons, Once and For All: The Ring of Solomon, the Cross of Christ and the Power of Biblical Kingship", Archiv für Religionsgeschichte 16 (2015), p. 99-130. 
even more appropriately, between the Law and someone called to act in compliance to it. The ring is used to impress a seal and to validate a binding contract, usually written on a metal or papyrus sheet or on any other valid support. The demon is compelled to respect the provisions of the spell, lest he be punished by a penalty, which the wizard has the power to enforce. The power of Solomon's ring lies in the essence of what it stands for: it constitutes the visual representation of a supreme agency that demons are bound to obey. Behind this typology of spells we can recognize a typology of magic with a highly structured approach, based on the recognition of a common principle of authority, which creates a sort of dialogue between the world of men and that of demons, that, although they are not to be trusted, are considered capable of interacting on a basis of parity and to understand the legal implications of breaking a contract.

The idea of entrapping demons in a closed space appears, on the contrary, to be more intuitive and less refined than the system just described. The entire discourse is based on a pre-verbal framework of action. The constraints in this case, in fact, are just physical, never logical or ethical. If the ultimate goal is the same - taming the evil spirit - the means through which this action is performed are very different. Here the demon is too dangerous to be dealt with and must only be sealed away, entrapped, enclosed. All this appears as the fruit of a more primordial, archaic level of interaction with uncontrolled forces. These two approaches are both present in the Testament and are often combined. However, I consider the fact of binding the demons through the ring and entrapping them in bottles as different manifestations (in technical terms) and this intrinsic difference certainly argues in favor of a distinct chronological and possibly cultural origin.

My interest, as said, lies in the relationship between the demon and the abode to which it is sometimes confined and it is therefore to this latter aspect, i.e. the entrapping, that I will now turn. Our text provides two different typologies of physical prisons for demons: a leather bag and a phiale, a water vessel usually employed for drinking purposes. Although both methods might appear quite similar at first sight, since they are both meant to physically entrap bodiless or protean demons, respectively wind- and water-like, I will argue that they represent the evolution of different paths, referring to two distinct origins. In my opinion, the former is much more 
ancient and seems to be broadly shared by the Semitic peoples; the second, on the contrary, is the result of a much more specific concern, historically defined. Despite an independent genesis, their inclusion in the Testament has contributed to flattening their original distinction. It is the conflation of these two motifs and their partial superimposition as similar techniques that has mostly contributed, in my view, to the final crystallization of the bottled demon topos.

\section{Ephippas, Aeolus's bag and Wind-Taming Techniques}

In Test. 22, the King of Arabia asks Solomon for help to get rid of a demon-wind blowing harshly in the region. The King of Israel therefore sends a servant boy with his ring and orders him to entrap the spirit in a leather flask. The bag is then brought to Jerusalem, where the demon, named Ephippas, is interrogated and later helps Solomon to set the cornerstone of the Temple in place. ${ }^{48}$

The episode in the Testament appears quite meaningful for various reasons: its geographical setting and the technique employed for capturing the demon, which corresponds to the one used by various cultures for controling the wind. It does not seem coincidental that this episode takes place in Arabia, a territory where we can observe a strong continuity of the wind-demon motif. A few centuries after this source, in fact, the Quran attests that Solomon is explicitly given power over winds and over jinn $(21: 81 ; 34: 11 ; 38: 36)$, an unsurprising fact, considering that jinn are, again by scriptural definition, born of the fire of the scorching desert wind (15:27). There is consensus among scholars that the origin of jinn dates back to a pre-Islamic phase, ${ }^{49}$ and their presence was already attested in the beliefs of the tribes from Arabia, ${ }^{50}$ as the passage in the Testament of Solomon seems to confirm. The text, of course, does not dwell on this

48. For a recent translation and commentary, see Busch, ed., Das Testament Salomos, p. 257-63.

49. A.S. Tritton, "Spirits and Demons in Arabia", The Journal of the Royal Asiatic Society of Great Britain and Ireland 4 (1934), p. 715-27; Michael MacDonald et al. "Djinn", in Encyclopaedia of Islam, Second Edition, eds. Peri Bearman et al., Brill Online, 2016; Robert Lebling, Legends of the Fire Spirits. Jinn and Genies from Arabia to Zanzibar, London, I.B. Tauris, 2010.

50. Jacquelin Chabbi, Le Seigneur des Tribus. L'Islam de Mahomet, Paris, Noêsis, 1997. 
specific aspect, having an altogether different focus, but the overall setting of the scene clearly draws on a body of extant convictions, rooted in Arabian lore.

The second interesting point to be underlined is the strategy adopted to capture the demon, which is enclosed in a leather flask. This method has a long history and a broad diffusion, representing another motif indexed in the Aarne-Thompson list (C322). In the text, the focus of the episode is on the capture of a demon but, originally, I think, the occurrence of the bag-motif probably developed in connection with wind-taming techniques and should therefore be ascribed to a set of archaic practices dealing with the control of natural forces..$^{51}$ This specific theme has been the object of various studies that have underlined how the custom of controlling winds, either by enclosing them in a bag or by restraining them through a series of knots, ${ }^{52}$ or by using both methods together, is particularly widespread. ${ }^{53}$ Certain scholars consider it a polygenetic motif, equally developed in various sailing societies worldwide, ${ }^{54}$ while others have nonetheless traced a partial filiation of motifs by explaining the famous Aeolus episode (Od. X, 1-79) as resulting from practices attested in northern Europe, where a strong sailing tradition clearly accounted for the development of such a motif. ${ }^{55}$

51. Wilhelm Fiedler, Antiker Wetterzauber, Stuttgart, Kohlhammer, 1931; Dietrich Wachsmuth, "Winddämonenkult", in Der kleine Pauly, ed. Konrat Ziegler, Stuttgart, Druckenmüller, 1964-75, 5 vols, V, col. 1380.

52. Even if the use of knots in magic practices is well attested for a variety of activities (such as love binding or general apotropaic functions), I wonder whether the quranic mention of woman blowing on knots $(113,4)$ did not originally refer to a method for raising winds, i.e. demons, in the specific cultural context of Arabia, understood as a dangerous or mischievous activity. On the entangled issue of the so-called Solomonic knot, see Allegra Iafrate, "Much ado about Knotting: the Intricate Story of Solomon's Interlaces", in preparation.

53. Jonathan G. Frazer, The Golden Bough, New York-London, Mac Millan, 1894; John Rhys, Celtic Folklore, Welsh and Manx, Oxford, Clarendon Press, 1901, 2 vols, I, p. 26-30; 330-1; Pietro Janni, Miti e falsi miti: luoghi comuni, leggende, errori sui Greci e sui Romani, Bari, Dedalo, 2004, p. 9-28.

54. Ludwig Rademacher, "Die Erzählungen der Odyssee", Sitzungsberichte der Kais. Akademie der Wissenschaft in Wien 178 (1916), p. 1-59, esp. 18-21; Reinhold Strömberg, "The Aeolus Episode and Greek Wind Magic", Symbolae Philologicae Gotoburgenses, 56 (1950), p. 71-84; Roland Hampe, Die Gleichnisse Homers und die Bildkunst seiner Zeit, Tübingen, Niemeyer, 1952, p. 16-7; Denys L. Page, Folktales in Homer's Odyssey, Cambridge, Harvard University Press, 1972, p. 73-8.

55. A.D. Fraser, "The Origin of Aeolus", The Classical Journal, 25 (1933), p. 364-66. 
It is not my intention to try to disentangle the intricate issue regarding the reciprocal influences of the story in anthropological terms, but I think it is worth dwelling on the figure of Aeolus, who, like Solomon, but many centuries before, was said to rule over the winds and entrap them in a bag. ${ }^{56}$ Even if a comparison between the Homeric episode and the Testament passage might seem far fetched, considering the context of compilation and their relative chronology, it is interesting to note traces of an undisputable continuity of themes between these two figures, not only during Late Antiquity but, possibly, even before. The National Museum of Copenhagen and the Kelsey Museum of Archaeology of the University of Michigan, for instance, hold two magic gems to be employed against colic, whose iconography probably depends on a third-century monetary type from Syria, representing a satyr with a wine bag. The current scholarly reading, however, posits a reinterpretation of the satyr type as Aeolus, here not simply as the ruler of the winds but, more likely, the personification of a demon capable of upsetting the belly (the leather bag) with spasms (figuratively interpreted as entrapped winds)..$^{57}$

But the points of tangency between Aeolus and Solomon are not limited to a late historical phase. On closer inspection, the common elements between the two figures appear not only numerous but also striking, and possibly reaching back to an ancient cultural stratum. To my knowledge, such a comparison is seldom mentioned and the first researcher to call attention to a sort of embryonic parallelism was Gabriel Germain in his Genèse de l'Odyssée. ${ }^{58}$ Germain dedicates a long analysis to Aeolus, showing how most of the features characterizing him should be ascribed to a typology of the primitive king-sage or king-priest, whose main activities and powers respond to the needs of an archaic society. He suggests that the bag of winds, the 'askos, corresponds to the "soufflet de forge" ${ }^{59}$ the forging bellows that were the main tool

56. Alfred Heubeck and Arie Hoekstra, A Commentary on Homer's Odyssey (books IX-XVI), Oxford, Clarendon Press, 1989, p. 43-4.

57. Campbell Bonner, Studies in Magical Amulets. Chiefly Graeco-Egyptian, Ann Arbor, University of Michigan, 1950, p. 66-7.

58. Gabriel Germain, Genèse de l'Odyssée. Le fantastique et le sacré, Paris, PUF, 1954 , p. 180 , p. 516-7.

59. Germain, Genèse de l'Odyssée, p. 182. 
of the blacksmith since, in antiquity, such an instrument would actually have been produced using animal skin. Aeolus is not only in control of natural elements, such as the winds; ${ }^{60}$ this ability also seems to hint at his dominion over metalworking techniques as well. He lives on a floating island, in a palace surrounded by bronze walls, a topos shared by various mythical figures, like Hephaestus himself, whose origin Germain traces back to the "Orient sumérosémitique", where the motif of the bronze wall and of dominion over winds are both to be found. ${ }^{61}$ And, as supporting evidence of such a connection in Semitic culture, the scholar mentions the three quranic passages seen above $(21: 81 ; 34: 11 ; 38: 36)$ that ascribe to Solomon control both over the wind and over metalwork (34:12). The latter skill is also explicitly mentioned in the Bible, both in reference to the giant brass basin (1 Kgs 7:23-26; 2 Chr 4:2-5) and, in general, to the furnishing of the Temple interior, described extensively in the same chapters.

The leather bag/winds/metals trajectory here outlined seems utterly convincing to me, since it also helps explain the subterranean logic that ties together several cultural elements ascribed to Solomon that can appear disjointed at first glance. To the examples listed by Germain, we should also add the nonscriptural but undoubtedly meaningful evidence of The City of Brass, a mythical city containing a series of Solomonic bottles as described in a famous tale in the Arabian Nights. Not unlike Aeolus's palace, this place is surrounded by an astonishing bronze/brass wall and it is filled with metal marvels, including robots, that call to mind those built by the goldsmith god Hephaestus in his own metal abode. The whole rich theme of the Solomonic automata, moreover, constitutes a further development of this notion, which connects wind and metalworking skills, since this specific class of objects could indeed be endowed with a voice, provided by the air that was often pumped through them by

60. The ability to control natural elements, such as winds, passes from Aeolus to his son Salmoneus, who, according to ancient sources, had a chariot with which he faked the noise of thunder and storms, a classical topos of cosmic kingship, derived from the notion of mastering the weather; Germain, Genèse de l'Odyssée, p. 187

61. Germain, Genèse de l'Odyssée, p. 189. Bronze mansions have a long history and a broad diffusion; see Denys L. Page, Folktales in Homer's Odyssey, Cambridge, Harvard University Press, 1972, p. 73-8. 
a bellows. ${ }^{62}$ The semantic constellation that Germain has traced for Aeolus seems therefore to apply to Solomon as well. I am not suggesting that there is a direct link between these two figures but it is interesting to underline how a certain set of features, typical of an archaic king-magus, can be found several centuries later, applied to the figure of Solomon. This evidence seems to represent the outcome of the survival and transmission of a much more ancient origin. ${ }^{63}$

Nevertheless, I would say that this represents only one part of the story. In fact, it seems possible to trace a similar path, according to a line developing along the elements leather bag/ winds/demons. As we have seen, the Quran bears witness, as does the Testament of Solomon a few centuries earlier, to a tradition that, according to the beliefs of the peoples of pre-Islamic Arabia, identified winds with demons. It seems possible to stretch this association further back in time in the Semitic world. The Old Testament, in fact, seems to provide more ancient traces of this connection. The most famous episode is probably that of the witch of Endor (1Sam, 28), who, interrogated by King Saul about his destiny, raised for him the spirit of dead Samuel. The necromancer is described in the Hebrew text as "a woman with an $o b$ ", and this terminological choice posed several hermeneutical issues to later interpreters [ill. 6].$^{64}$ The word $o b$ - literally related to "hollow sound" - can in fact, be variously translated. The BDB lexicon lists four different entries: "skin bottle" (Job 32:19), "necromancer" (Lev. 19:31; 20:6, 27; Deut 18:1; Sam. 28:3, 7, 8, 9; 2 Kgs 23:24;

62. For a synthetic overview on the topic, see Allegra Iafrate, The Wandering Throne of Solomon: Objects and Tales of Kingship in the Medieval Mediterranean, Leiden, Brill, 2015.

63. Along this line, it is also interesting to remark that an ancient Pythagorean tradition assimilated the sound produced by resounding bronze to the voice of the demon enclosed within it; on this, see Marcel Détienne, Le notion de daïmôn dans le pythagorisme ancien. De la pensée religieuse à la pensée philosophique, Paris, Les Belles Lettres, 1963, p. 50.

64. It is interesting to note that the witch of Endor is represented holding a sort of flask in a German fifteenth-century print. For its reproduction, see Zika, The Appearance, ill. 2.12, p. 49-50. The author suggests that we may see in this iconographical detail a reference to the "cup of abomination", since the whole depiction appears to be a conflation of motifs from the Apocalypse (the prostitute from Babylon) and the Samuel passage. I think that such a hypothesis is very reasonable, although it would have been interesting to explain the presence of the "bottle" on the basis of a rather too literal translation of the term $o b$. 
Isa 8:19; Isa 19:3, 2 Chr 33:6=2 Kgs 21:6;), "ghost" (Isa 29:4) and "necromancy" (1 Chr 10:13). ${ }^{65}$

The superimposition and substantial interrelatedness among the three latter meanings, considered a successive and later development of the word, and the apparently elusive semantic distance from the first entry, are quite interesting. There is, however, a definite connection. The idea behind it is, in fact, an acoustic one. The necromancer is really someone capable of making spirits talk and the voice they produce is a hollow sound, probably similar to that made by the wind, when entering a leather skin. This explains why various biblical interpreters, in order to translate the periphrasis indicating the witch, choose "ventriloquist", someone speaking from his belly, a term that is equated in a simile to a wineskin (Job 32:19). When Isaiah speaks of necromancers for the first time (Isa 8:19), moreover, he insists on the muttering quality of their voice and also reinforces the sound dimension of their activity in a second passage, stating that it is similar to speech coming from the ground and to whispering through the dust (Isa 19:3).

We can wonder whether this strong link between the sound made by air in a leather bag (or blowing from the hollow cavities of the ground) and the voice of a spirit should be understood only on a metaphorical level. This revealing correspondence could have in fact originated in the ancient custom of imprisoning the wind in this type of sack.$^{66}$ The Bible does not provide us with clear evidence that the wind was to be considered an evil spirit ${ }^{67}$ but if we look

65. The issue is well summarized and discussed in Rowan Greer, The "BellyMyther" of Endor: Interpretations of 1 Kingdoms 28 in the Early Church, Atlanta, Society of Biblical Literature, 2007, p. xi-xii.

66. As some nineteenth-century scholars concluded, positing, maybe a bit cavalierly but, all in all, perhaps not incorrectly, "[...] the antiquity of the idea that magicians were wont to imprison in bottles the spirits whom their spells had subdued (whence our 'bottle-imps' and 'bottle-conjurors)", Chamber's Encyclopaedia. A Dictionary of Universal Knowledge for the People, London, W. \& R. Chambers, 1874, 10 vols., IV, p. 239.

67. However, a trace of this idea seems to be found in the episode from the Gospel of Luke in which Jesus commands the winds and tames the storm. The demonic quality of these winds interestingly resurfaces in some Medieval manuscripts that depict the episode, even if this is probably "the result of medieval imagination" rather than a trace of the ancient tradition; Alessandro Nova, The Book of the Wind: The Representation of the Invisible, Montreal, McGill-Queen's University Press, 2011, p. 49-50. Control over natural elements, perceived as 
at close-by Mesopotamia, to the terrible wind-demon Pazuzu, one of the worst creatures of the Babylonian pantheon, there is ground to posit, on a tentative level, that such a connection might have existed at some point. ${ }^{68}$ Pazuzu is a demon of pestilence, favoring contagion by blowing around mephitic air. However, he is not an original creation of Babylonian mythology but, based on the etymological origin of the name, scholars have posited a Semitic origin for him, which was introduced not prior to the Iron Age. ${ }^{69}$ Pazuzu is never explicitly entrapped in any sack, but his very existence and likely origin could represent indirect evidence of the specific tradition that resurfaces among the tribes of Arabia.

All these, of course, are just small fragments of a discourse that is almost entirely lost to us, but they nonetheless favor a certain interpretation: there seems to be, among the ancient Semitic peoples, a common belief associating evil spirits and winds. This notion, more subdued in the Bible, seems indirectly supported by the term $o b$ and

evil forces, appears to be a sort of long-standing reminiscence of the discourse outlined above. I also wonder whether the famous, almost proverbial, quote by the prophet Hosea, "who seeds wind shall harvest storm" (8:7), usually interpreted as a prophesy of the vengeance to come, may not instead be the reflection of an actual practice concerning sympathetic magic employed in order to control the wind. Various sources report that sailors used to whistle to raise the wind in case of a dead calm. However, it is also known that such a practice, when not well performed, could transform a gentle breeze into a fierce storm. The reference made by the prophet, then, seems to hint at something not very dissimilar. The phrase "seeding wind", here employed as a figure of speech, could ultimately derive from a more specific practice meant to invoke the wind, with consequences not always predictable or easily controllable. On a Medieval example of this occurrence, see, for instance, Pietro Janni, "Il naufragio di Martiniano", in Curiositas. Studi di cultura classica e medievale in onore di Ubaldo Pizzani, ed. Alessandra Di Pilla, Antonino Isola and Enrico Menestò, Napoli, ESI, 2002, p. 311-4. In general, on wind during the Middle Ages, see Jean-Pierre Leguay, L'air et le vent au Moyen Âge, Rennes, Presses Universitaires de Rennes, 2011.

68. Frans A.M. Wiggermann, "The Four Winds and the Origins of Pazuzu", in Das geistige Erfassen der Welt im Alten Orient, ed. Claus Wilcke, Wiesbaden, Harrassowitz Verlag, 2007, p. 125-65.

69. Wiggermann, "The Four Winds and the Origins of Pazuzu", p. 135-6. The etymology of the name and the whole genealogy of the demon are quite uncertain; some scholars see it as deriving from a Semitic root meaning "cripple" or "dwarf" and for Pazuzu's father's name the etymology proposed is "the limping one". This aspect is interesting because, in a curious coincidence, several demons appearing in late Western culture are said to be limping. Given the tremendous chronological distance between these points and the numerous uncertainties regarding the origin of the term, I do not intend to push this parallel any further but it is certainly fascinating to imagine that such an ancient feature may have survived and been transmitted. 
by the semantic field associated with it. In the Islamic world, the connection appears more obvious, since the Quran retains explicit traces of it, although it does not mention the leather bag as a possible means of constraint, which appears, instead, in the Testament. The account in this latter text, therefore, seems to represent a trace of this ancient custom, where all elements are put back together. As seen at the beginning of this section, the idea of constraining the wind is particularly widespread and it is one of those themes that are relevant in broad anthropological terms. ${ }^{70}$ Of course this remains true, but it seems possible to suggest, as far as the Solomonic case is concerned, that this material merged together and was ascribed to him through a direct filiation via the Semitic heritage that he shares.

\section{Kynopegos, The "Recycling" Process of Sukkot Bottles and Healing Practices}

Probably more famous than the leather flask, however, is the theme of Solomon's bottles, strictly connected, at least originally, to water demons. While the previous case is more problematic to treat, given its ramifications and anthropological parallels, the core of this tradition, as I have briefly discussed elsewhere, appears to be rooted in a specific historical context and strongly anchored to the city of Jerusalem, even if its successive development will progressively lose trace of its distinctive origin. ${ }^{71}$ Solomonic "bottles" are mentioned only in a few apparently unrelated texts, different in scope, compilation context and chronology. Nevertheless, they all seem to develop from a common cultural nucleus. The Testament, which constitutes the starting point of my analysis, deals with the episode in connection

70. In the ancient Greek conception, for instance, there is a clear connection between the archaic and monstrous Thyphon, son of Gea and Tartarus, and strong winds and storms. Along this line, we should also recall that the subterranean winds that were thought to be the cause of earthquakes were often represented as demons, given also the ambiguity of the term pneumata (Aristotle, Met., II, 8, 368 and 26-34); see also Hans Lewy, Chaldaean Oracles and Theurgy. Mysticism, Magic and Platonism in the Later Roman Empire, ed. M. Tardieu, Paris, Madan, $1978^{3}$, p. 259 , n. 2 . As for the simile between speaking demons and winds, see the examples collected by Daniela Coppola, Anemoi. Morfologia dei venti nell'immaginario della Grecia arcaica, Naples, Liguori, 2010, p. 113-9.

71. Allegra Iafrate, "Solomon, Lord of the Rings: fashioning the Signet of Power from electrum to nuhās", al-Masaq, 28 (2016), p. 1-21. 
with the capture of the sea demon Kynopegos (Test. 16:1-7), which takes the shape of waves and causes shipwrecks. Solomon puts him in a phiale, that is, a typical drinking vessel, along with ten jugs of sea water, and seals the mouth of the vessel with asphalt, ordering it to be deposited in the Temple. ${ }^{72}$ The solid, metal-like quality of the vessels described in this example (as was the case for the wind) appears to be useful for entrapping demons that take on liquid forms, or are broadly identified with the medium they live in. And there seems to be a sort of continuity in the development of later traditions concerning water demons: the Fisherman and the Bottle, a tale collected in the Arabian Nights, stages the recovery of a bottled-up jinni in the sea, but, even before this, the demon Ashmedai is often shown in close relationship with deep water/wells/cisterns, as in the Babylonian Talmud (Gittin 68b). This could be a faint echo of the original use of the bottle, which develops in connection with water.

Parallel to the description of the Testament is the account provided by the Testimony of Truth, a second/third-century gnostic text found in Nag Hammadi in Egypt. ${ }^{73}$ It describes Solomon and his methods in a highly polemical way and mentions how for a long time "seven waterpots" lay abandoned in the Temple of Jerusalem, containing demons imprisoned by Solomon, who were then cast free and caused great damage, once the Romans took the city. ${ }^{74}$

The third text that mentions Solomon, bottles and demons is a Syriac treatise, a translation from a text probably compiled around the fourth century by Egyptian alchemist Zosimus. In the chapter dedicated to the metal electrum, the author mentions seven bottles

72. Busch, Das Testament Salomos, p. 211-4.

73. It is interesting to note that a strong relationship between winds and demons is also to be found in some Gnostic writings, such as the Paraphrase of Shem. For a passage from the text in translation, see The Nag Hammadi Library in English, ed. James M. Robinson, Leiden, Brill, 1984, p. 317-9.

74. "Others have demons dwelling with them, as did David the king. He is the one who laid the foundation of Jerusalem; and his son Solomon, whom he begat in adultery, is the one who built Jerusalem by means of the demons, because he received power. When he had finished building, he imprisoned the demons in the temple. He placed them into seven waterpots. They remained a long time in the waterpots, abandoned there. When the Romans went up to Jerusalem, they discovered the waterpots, and immediately the demons ran out of the waterpots, as those who escape from prison. And the waterpots remained pure thereafter. And since those days, they dwell with men who are in ignorance, and they have remained upon the earth", Birger A. Pearson, "Gnostic Interpretation of the Old Testament in the "Testimony of Truth' (NHC IX,3)", The Harvard Theological Review 73 (1980), p. 311-9, p. 315. 
brought from Jerusalem to Egypt, invented by Solomon to entrap demons. The term "qwl" (sing. qūlo, pl. qūle) literally indicates a "pitcher, an ewer, a cruse" 75 or a "hydria, lagena" 76 - again containers mostly used for water. According to the alchemist, moreover, they were used by the high priests in relation to the inferior abyss ("thūmō") of Jerusalem.

Although the two latter texts are not at all related, they seem to refer to a common tradition that was clearly circulating in Egypt in Gnostic contexts during the same chronological arch, between the second and the fourth centuries. According to it, in the dungeons of the Temple of Jerusalem there were water containers believed to contain demons. Zosimus' text seems to provide a faint hint that helps clarify how such an idea originated. The abyss mentioned ("thūmō") is in fact a literal translation of the Hebrew tehom, a highly meaningful word, referring to the primordial waters of chaos, the same that had caused the flood. According to the Jewish tradition, the Temple of Jerusalem was founded on such an abyss and acted as a sort of sacred threshold over it. As such, it was the core of Sukkot celebrations, at least as it was performed during the second Temple period. The Mishna indicated a series of rituals requiring tellurian waters such as these on the occasion of such a major festival, during which the priests had to draw water with a golden pitcher for seven days and make a libation on the altar, probably as a rain and fertility ritual. ${ }^{77}$ This dense theological situation mirrored a factual reality: Jerusalem does stand on a hollowed out ground, under which run subterranean waters, some of which had been channelled from the Gihon spring into the Siloam stream as early as 700 B.C.E. by King Hezekiah. Quite interestingly, the ritual of Sukkot required seven pitchers, one for each day of the celebration, and it was performed until 70 C.E., when the Temple was destroyed by the Romans. Considering the centrality of the Temple and of its altar for the reasons above mentioned, the celebration of Sukkot underwent major changes following the destruction in 70 C.E., as Tannaitic

75. Jessie Payne Smith, ed., A Compendious Syriac Dictionary, Oxford, Clarendon Press, 1903.

76. Robert Payne Smith, ed., Thesaurus syriacus, volumes I-II, Oxford, Clarendon Press, 1879.

77. Jeffrey Rubenstein, The History of Sukkot in the Second Temple and Rabbinic Periods, Atlanta, Scholars Press, 2006, reprint from 1995, p. 117-31. 
sources demonstrate. ${ }^{78}$ The Temple could no longer be used and the water libation ceremony was abandoned and substituted with a series of prayers that were meant to have a similar effect on the rain.

The Testimony of Truth, therefore, seems to evoke a probable scenario. The seven ritual water pots could have been still lying forgotten in the subterranean chambers (or, at least, their memory still lingered) in the ruins of the edifice, and it is not surprising that, in the course of the Roman dominion over Jerusalem, someone may have seen them or evoked their presence. Of course, there is no need to posit the factual presence of these vessels; what counts is that their presence was established in historical memory and their context of provenance was deeply imbued with symbolic implications.

Nevertheless, the Sukkot rituals just described have nothing to do with demon control and originally the bottles were not meant to be used in that way. It is not impossible, however, that such an idea developed immediately after the celebration ceased to be performed. It is to be noted, in fact, that, at least in the Christian perception, the tehom was already considered to be the dwelling place of demons toward the end of the first century of the Christian era, when the Revelation (17:41) and the Gospel of Luke (8:31) were compiled. It seems therefore likely that the association between the subterranean waters of Jerusalem, the demons and the pitchers must have begun to take shape only after the Temple destruction, maybe around the end of the first century. However, the presence of Solomon seems due to an altogether different tradition.

In one of the earliest pilgrimage accounts that have come down to us, dated around 333-334 C.E., it is in fact reported that in proximity to the pools of Bethesda ${ }^{79}$ whose waters had been renowned for their curative powers ever since the first century, there was also a crypt or a cave where Solomon bound demons ("est ibi et cripta, ubi Salomon daemones torquebat"). ${ }^{80}$ The source does not add anything else; from archaeological research,

78. Rubenstein, The History of Sukkot, see in particular chapter 4, "Sukkot and Rain in Tannaitic sources".

79. The site is mentioned in the Gospel of John (5:2-18) as the setting of a miracle performed by Jesus.

80. Itinerarium Burdigalense, 598, 7-11, ed. P. Geyer and O. Cuntz, in Itineraria et alia geographica, Corpus Christianorum, Series Latina CLXXV, Turnholt, Brepols, p. 14-5. 
however, we know that the place was already a famous healing site visited by many invalids ever since the first century B.C., when an Asklepeion was built in the area. ${ }^{81}$ The Solomonic cult, then, as often happens, grew out from an already established tradition and it is possible that, in this transition process, Solomon acquired some of the traits of the Greek demigod and of his powers.

According to Augusto Cosentino, this cave was, in all likelihood, a veritable sanctuary holding various "Solomonic relics", a site where exorcism rites were performed and people were healed, and where the tradition of the bottles containing demons probably got firmly established. ${ }^{82}$ It is interesting to note that, according to this source, too, we have a strong link with the waters of the city and with a subterranean dimension of the cult, although these pools are not related to those of Siloam. It therefore seems to me that at some point these two traditions merged and some confusion occurred. The two Gnostic sources above mentioned, in fact, seem to bear traces of a superimposition; they preserve the number of ritual bottles abandoned in the Temple, the subterranean waters of the tehom, Solomon, the bottles and the high priests - a series of elements that, as seen, probably referred to different pools and to chronologically and culturally distinct rituals: a Jewish fertility festival and a Judeo-Christian exorcism/healing tradition.

The Solomonic bottles make a new appearance in the sixthcentury revision of the so-called Breviarius de Hyerosolima, originally a fourth-century topography for Christian pilgrims. The text describes the church of St. Constantine and says: "around this apse stand twelve quite marvellous columns of marble, and on these columns are twelve silver bowls ('hydriae') in which Solomon sealed the demons". ${ }^{83}$ Here, the containers are not seven but twelve, a number that seems to follow a more definite Christian

81. Pierre Benoit, "Découvertes archéologiques autour de la piscine de Béthesda", in Jerusalem through the Ages: the Twenty-fifth Archaeological Convention, October 1967, ed. P.W. Lapp, Jerusalem, Israel Exploration Society, 1968 , p. $48-57$, p. $52-3$.

82. Augusto Cosentino, "La tradizione del re Salomone come mago ed esorcista", in Gemme gnostiche e cultura ellenistica, ed. A. Mastrocinque, Bologna, Pàtron, 2002, p. 41-59, p. 43. A contribution by the same author (The Solomonic Shrine in Jeruslem and the Exorcisms agains Evil Spirits, provisional title), specifically dedicated to the cave-sanctuary, is in preparation.

83. John Wilkinson, Jerusalem Pilgrims before the Crusades, Warminster, Aris \& Phillips Ltd, 2002, Breviarius, version A2, p. 117. 
symbolism. These water pitchers were set in a context where Baptismal practices were held, thus openly crediting the rite with a strong purifying effect with respect to evil possession. We do not know how early these pitchers were placed in the church or how and whether this new location represented an update of the rituals taking place in the crypt/cave close to Bethesda.

Furthermore, abbreviated traces of the same tradition that connect Solomon with bottles containing demons also resurface later on in other sources written in Greek. Once more, we owe these latter occurrences, virtually unknown to the scholarly world, to Bonner, who traced them in the Disputatio cum Herbano Judaeo, possibly a sixth-century text by Gregentius, bishop of Taphar, in the Life of Saint Philip of Agyrium, a famous exorcist, handed down by twelfthcentury manuscripts but possibly dating to around the tenth century, and also found in an eighteenth-century text, published by Mc Cown as an appendix to his translation of the Testament. ${ }^{84}$

Extant evidence suggests that, while there is nothing explicitly connecting Solomon with bottles before the end of the first century C.E., there is much afterwards, as another well-known Arabic tale already mentioned, The City of Brass, demonstrates. This story not only mentions a city surrounded by a bronze wall, but also revolves around the expedition leaving Damascus during the seventh

84. The story emerging from both the Testament and the other texts mentioned is echoed by two passages of a late Greek text, a Solomonic diegesis mostly compiled in 1719 and published by McCown as an appendix to his translation of the Testament, X, 2: "After the completion of the temple of God, King Solomon gathered together all the demons and unclean spirits, and caused to stand before him an innumerable multitude of demons; and he gave command that skilled artificers who worked in copper should come, and he ordered them to make copper vessels. And then he took and made large casks like jars and the King commanded all the demons in the name of God and they entered into those vessels of copper. And then the King himself took and shut them up, and sealed the vessels with the seal of God. And the seals were of silver and the demons were within; and they dared no more go forth"; XI, 3-4: "Then came also King Nabuchodonosor from Babylon and he took Jerusalem and sacked it; and then he burned the roof of the temple built by Solomon, who had roofed it over entirely with pure gold; as it burned the gold ran like a great river...and the Chaldeans, who plundered Jerusalem, in their plundering found those copper vessels in which King Solomon had shut up the demons and sealed them with the seal that God sent him from heaven by the archangel Michael. And when the Chaldeans saw the golden seals and those copper vessels, which were buried in the earth, and looked like wells sealed up, the Chaldeans believed that they were a hidden treasure, and they went and unsealed the golden seals from them; and the demons fled and plagued men again", Bonner, "The Sibyl and Bottle Imps", p. 5-7. 
century in order to retrieve the Solomonic bottles containing the entrapped jinn..$^{85}$ Interestingly, the original nucleus of this tale was composed in the Maghreb, probably around the ninth century, and the city in which the bottles are eventually found is in Egypt, ${ }^{86}$ yet another trace of how the story of the Solomonic bottles enjoyed a strong circulation in the same area for various centuries, even after Late Antiquity. The account collected in the Nights seems to represent the last and possibly most popular outcome of the tradition I have just finished outlining, this time set in the Islamic world. And it is through it that it came to be known also in the Western world, although it is not where it originated.

\section{Conclusion}

The theme of the spirit in the bottle and of the leather bag are both listed in the Aarne-Thomson folkloric index (331 and C322). As such, they enjoy a broad chronological and geographical diffusion and, as often happens with this kind of motif, it is difficult and often not methodologically correct to trace a precise filiation path, since some of these could have a polygenetic origin. My contention, however, is that the story of the devil entrapped in a container, so popular in the Western world, although possibly paralleled in examples of distant peoples, can be traced back to a specific historical moment, and more precisely to a phase, probably beginning at the end of the first century C.E., during which different traditions regarding the entrapment of demons in closed vessels began to circulate more broadly. The description of the Sibyl in the Satyricon seems to represent an echo, however independent, of such a process, paralleled by the traditions

85. Mia I. Gerhardt, The Art of Story-telling: A Literary Study of The Thousand and One Nights, Leiden, Brill, 1963; Andras Hamori, "An Allegory from the Arabian Nights: the City of Brass", Bulletin of the School of Oriental and African Studies, University of London 34 (1971), p. 9-19; Andras Hamori, On the Art of Medieval Arabic Literature, Princeton, Princeton University Press, 1974; David Pinault, Story-telling techniques in the Arabian Nights, Leiden, Brill, 1992; Jocelyne Dakhlia, Le divan des rois. Le politique et le religieux dans l'Islam, Paris, Aubier, 1998, p. 203-23; Julia Hernández Juberías, La Península immaginaria, Madrid, CSIC, 1999, p. 208-48. For the Solomonic overtones of the tale, see in particular Bruce Fudge, "Signs of Scripture in 'The City of Brass"”, Journal of Quranic Studies 8 (2006), p. 87-118.

86. Gerhard, The Art of Story-Telling, p. 212-3. 
that began to explicitly ascribe these techniques to Solomon in the same arch of centuries and that were collected together in the Testamentum Salomonis. This famous handbook of demonology contributed enormously to the notion that the King of Israel, in his capacity as an exorcist, could force demons into various containers and could make them perform a series of deeds. The text is a repository of materials of different provenances and chronologies that were reworked together in a way that does not always enable a precise recognition of all cultural threads and that represents, in my view, the coming together of the various elements in the story. As I have tried to demonstrate, for instance, the two apparently similar episodes regarding the imprisonment of the water-demon Kynopesigos and of the wind-demon Ephippas, respectively in a phiale and in a leather bag, represent the point of arrival of two distinct and distant stories. The former probably combines together the bottles once used for the Sukkot ritual, the demons living in the abyss under Jerusalem and long-standing healing practices of the city, while the latter depends on the ancient tradition, well known to the Semitic heritage, that identifies winds, demons and pestilences with one another and tries to control them. Through the partial superimposition of these themes in the Testament, then, the late antique Solomon acquired a series of features typical of the king-priest of archaic societies, also shared by mythical figures like Aeolus, that ended up being repeated and transmitted through several midrashic, folkloric or legendary accounts circulating about him in the course of the Middle Ages. In this way, this nucleus of motifs became a strong and consistent topos that penetrated into European culture, either through a direct filiation or through the parallel mediation of Virgil, who had inherited the vessel and its dangerous contents, through legends that had been attached to him at least since the thirteenth century. The demon entrapped in the ampoule thus became the symbol of the necromancer par excellence, even if its origin and the complex chain of passages leading to its creation was partially erased in the process. Nevertheless, the demon in the ampoule is no different from a message enclosed in a bottle that finally drifts ashore when the wind and water cease their fury: if opened carefully, it can still be read as the trace of a longer and much more adventurous story. 


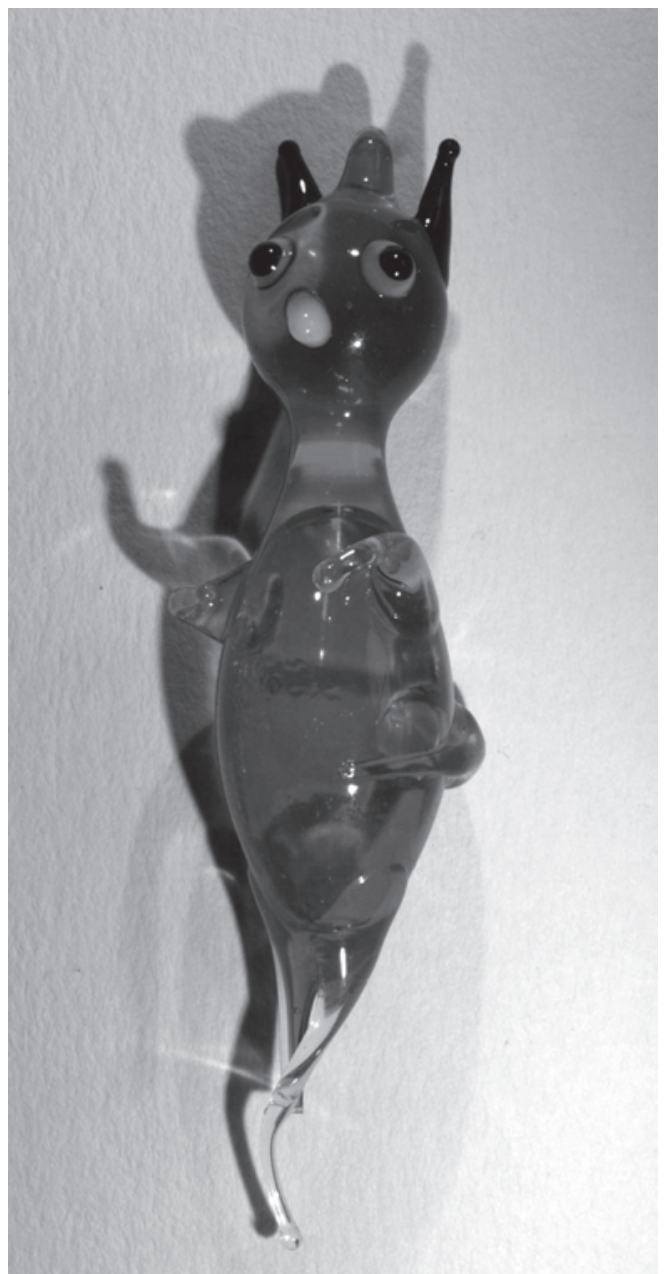

Fig. 1. Cartesian devil

Work by Hannes Grobe

Photo (C) Creative Commons CC-BY-SA-2.5

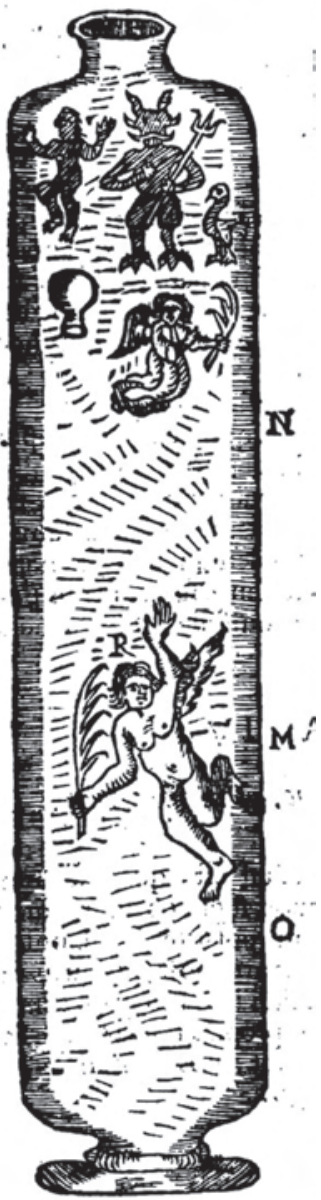

Fig. 2. Devil-buoy employed for Magiotti's experiment Taken from Athanasius Kircher (1602-1680)

Magnes, sive de arte magnetica

(Roma: Vitalis Mascardi, 1654) 


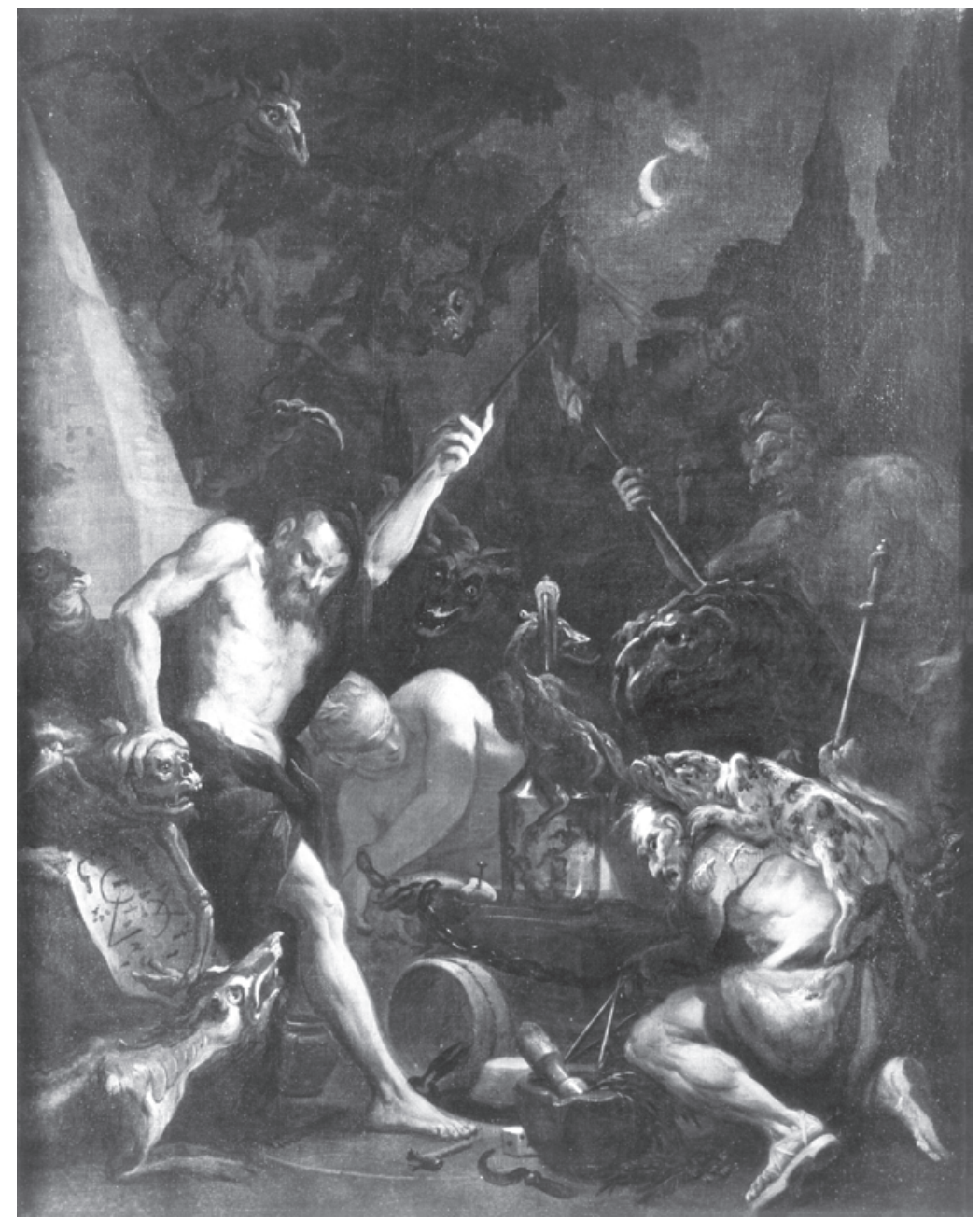

Fig. 3. Pier Dandini (1646-1712), Witchcraft

Firenze, Private collection

Photo (C) Courtesy of Sandro Bellesi 


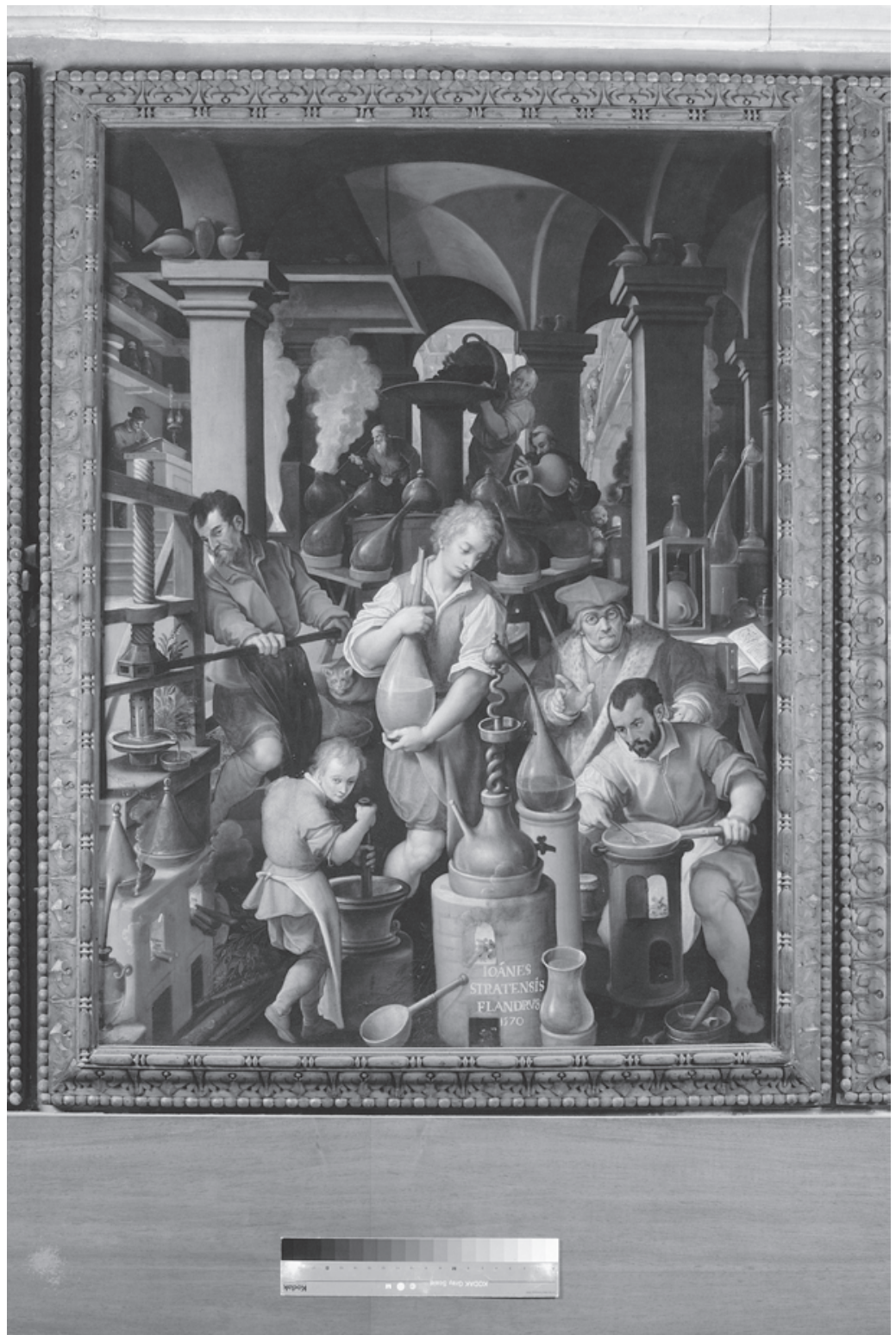

Fig. 4. Jan van der Straet [Giovanni Stradano] (1523-1605), The Alchemist's Studio

Firenze, Palazzo Vecchio, Studiolo of Francesco I Photo () Allegra Iafrate 




Fig. 5. Creation of the homunculus

Taken from J.W. Goethe, Faust, mit Bildern von F. Simm

(Stuttgart: Deutsche Verlagsanstalt, 1899) 




Fig. 6. Pythonissa, Taken from Paul Kristeller,

Holzschnitte in Königl. Kupferischkabinett zu Berlin

(Berlin: Cassirer, 1915), table LXXXXVII 